\title{
THE JEWISH SALAD BOWL WITHIN THE AMERICAN MELTING POT: A LITERARY CONTEMPLATION
}

\author{
Elonora Hodaj, University of Vlore "Ismail Qemali", Albania, \\ elonorahodaj1617@gmail.com
}

10.31902/fll.27.2019.3

UDK 821.111.09

\begin{abstract}
Human history has always been characterized by repeated cycles of crisis and transitional periods bringing about transformation in various aspects of people's coexistence and interaction with each other be it on the individual, ethnic, national, or even the international level.

Currently, we have become eyewitnesses of what can be called the modern times crusades and exodus. The present free movement of people imposed by the globalization trend in contemporary society and particularly the new wave of migration with its relevant migrant crisis set in motion by numerous armed conflicts in the Middle East, will undoubtedly establish new relations among them, among ethnicities, among groups of different religious affiliation and even between migrants and host countries.

In the course of these historical transitional periods, the concerned entities have always tried to define and explain such human relations and interactions that can vary from assimilation to multiculturalism. The two prevailing metaphors used to give a definition to the new forms of language, customs and cultural coexistence are those related to the notions of melting pot and salad bowl, which will be contemplated over with literary reference to Grace Paley's “The Loudest Voice” and Cynthia Ozick's "Envy; or Yiddish in America". In both these writings, the need to transcend alienation, as well as the preoccupation to express belongingness in some naturalistic American premises, will hint at a relevant, analogous strive for identification to that of the migrants roaming the streets of Western Europe in search of a peaceful place to dwell and cohabitate with the host country and the implied culture.
\end{abstract}

Key words: assimilation, multiculturalism, melting pot, salad bowl, cultural belongingness.

The everlasting movement of people from one country to another, imposed by historical transitional periods as well as the globalization trend in contemporary society has transformed various aspects of peoples' coexistence and interaction with each other. Currently, we have become eyewitnesses of what can be called the modern times crusades and exodus. The present free movement of people and particularly the new wave of migration with its relevant migrant crisis 
set in motion by numerous armed conflicts in the Middle East will undoubtedly establish new relations among them, among ethnicities, groups of different religious affiliations and even between migrants and host countries.

In the course of these occurrences, the concerned entities have always tried to define and explain such individual, national, or even international human relations by means of language. The two prevailing metaphors used to give a definition to the new forms of lingual and cultural coexistence, which can vary from assimilation to multiculturalism, are those related to the notions of melting pot and salad bowl. As we know, the melting pot theory requires that immigrants assimilate in order to become one common culture, whereas the salad bowl theory basically calls for celebration of our diversity along with our oneness.

Social issues spanning a broad range of complex discussions on involved religious, racial, or ethnic groups are often part of this direct, mutual and interactive relation between language and society. Consequently, the emergence of dominant and minority groups becomes a feature of these cultural encounters where the dominant group is able to set the standards of what is worthy and respectable in cultural values and social behavior. Unsurprisingly, it chooses its own styles while the stereotypes minorities create of the dominant group typically make reference to their own victimization.

It is curious how all of the abovementioned clues can serve as milestones in this present contemplation with literary reference to two twentieth century short stories by two contemporary American Jewish writers; Grace Paley's "The Loudest Voice" (1959) and Cynthia Ozick's "Envy; or Yiddish in America" (1969). In both these writings, the authors' concern with the nature of language unfolds the need to transcend alienation, as well as the preoccupation to express belongingness in some American-English lingual premises which in turn will impose and instill a certain way of thinking and understanding of the world in the characters striving for identification and recognition.

The present paper will start with Cynthia Ozick's conservative devotion to Jewish heredity and holocaust's memory and follow with Paley's liberal celebration of America's multicultural community.

"Envy; or Yiddish in America" is a satiric comment on the nature of Jewish literary culture in the United States written in broad comic strokes and at the same time an ironic treatment of a serious theme - the isolation of the American Jewish intellectual who clings to his old European tradition. 
Cynthia Ozick is overtly Jewish in her extraordinary commitment to Jewish heritage and memory of the Holocaust. Her consciousness was forged in the traditions and sufferings of the Jewish people. One of the topics that Ozick could not avoid in her fiction is the way in which Jewish identity has been marked by the Holocaust. She complicates this question of identity by portraying her protagonist's persistent attempts to distance himself from the American society in terms of ethnicity, religion, class and even language. But of course, culture and tradition cannot exist in a vacuum. They find their exuberant expression in language with a kind of interaction operating between the two, language and culture.

Ozick expresses her concern with the nature of language and its connection to culture in a clearly designated topic in the title "Envy; or Yiddish in America". It is a short story which takes place in New York City, where Hersheleh Edelshtein, son of a Polish Hebrew tutor, has lived for forty years. The narrative follows Edelshtein's point of view, an aging Yiddish poet who centers his life on his all-encompassing jealousy of Yankel Ostrover. Edelshtein writes Yiddish poetry for an obscure publication edited by his fellow friend, Yiddish poet Baumzweig. Ostrover, the story teller, is the only Yiddish writer in America whose work is regularly translated. $\mathrm{He}$ is a disguised allegorical character representing Isaac Bashevis Singer (1902-1991), the most distinguished American author who wrote in Yiddish, while achieving world-wide fame in English translation. Aware that his work belonged to more than one culture, to him the essential subject of literature was the reflection of the combinations and complications of heredity and environment. In "Envy; or Yiddish in America", the protagonist of Ozick's short story is a first generation immigrant to the US, an elderly Jewish poet, desperate for having lost almost all of his readers since they have either perished in the Holocaust or given up mamaloshen, their Yiddish mother tongue for the language of their new hosting country.

Edelshtein's poetic and literary strive seems to go in reverse with that of Singer's wit, thus the outcome is predictable and justified:

He traveled from borough to borough, suburb to suburb, mourning in English the death of Yiddish. Sometimes he tried to read one or two of his poems. At the first Yiddish word the painted old ladies of the Reform Temples would begin to titter from shame, as at a stand-up television comedian. Orthodox and Conservative men fell instantly asleep. So he reconsidered, and told jokes.[...]But both Edelshtein and his audiences found the jokes worthless. 
Old jokes. They were not the right kind. They wanted jokes about weddings-spiral staircases, doves flying out of cages, bashful medical students-and he gave them funerals. To speak of Yiddish was to preside over a funeral. (Ozick, 2)

In his research work "Language and Culture" Kramsch (1998) identifies three ways in which language and culture are linked together. Through the act of speaking, we take on social and cultural roles which are so deeply embedded in our process of thinking that go frequently unnoticed.

According to Kramsch, language "expresses, contains and symbolizes cultural reality"1(Kramsch, 3). Set within "Envy; or Yiddish in America" such a theory would apply to Edelshtein's impressions on his strenuous experience as the Jewish immigrant in America. Through words not only does Edelshtein express his perceptions of how this mass assimilatory society corrupts the Yiddish ethnic awareness by murdering its memory and language, but he also reflects on his position related to his fixed schemes of perceiving his world.

A little while ago there were twelve million people-not including babies-who lived inside this tongue, and now what is left? A language that never had a territory except Jewish mouths, and half the Jewish mouths on earth already stopped up with German worms...And the language was lost, murdered. The language-a museum. Of what other language can it be said that it died a sudden and definite death, in a given decade, on a given piece of soil?[...]Yiddish, a littleness, a tiny light-oh little holy light!-dead, vanished. Perished. Sent into darkness. (Ozick, 16)

Moreover, through language, Edelshtein makes sense and organizes his experience of the real world.

Nowadays the Jew is forgetful, everybody with a profession, every Jewish boy a professor-justice seems less urgent. Most don't realize this quiet time is only another Interim.[...]Once we were slaves, now we are free men, remember the bread of affliction.[...]Naturally the important thing is to stick to what you learned as a slave including language, and not to speak their language,

\footnotetext{
${ }^{1}$ Italics, mine.
} 
otherwise you will become like them, acquiring their confusion between God and artifact and consequently their taste for making slaves, both of themselves and others. (Ozick, 16)

Edelshtein views Yiddish and its preservation respectively as symbol of Jews' social identity and their lifelong mission in the assimilatory American society.

Hannah, youth itself is nothing unless it keeps its promise to grow old. Grow old in Yiddish, Hannah, and carry fathers and uncles into the future with you. [...] Hannah, you have a strong mouth, made to carry the future. [...] Do this. You, one in ten thousand maybe, who were born with the gift of Yiddish in your mouth, the alphabet of Yiddish in your palm, don't make ash of these!(Ozick, 16)

Thus, Edelshtein rejects English in favor of Yiddish and laments that his language is dying. For him, the loss of Yiddish and old values is the loss of an entire world. He desperately seeks a translator who he thinks will make his ascending up the ladder of the literary success as a poet possible. The fact that his English is too poor, despite his forty years in America, counts for the persevering resistance of national consciousness. As a counter epitome of such continuity, Hannah, a young intelligent Jewish girl born in America and fluent in Yiddish refuses Edelshtein's request for the translation in English of his literary works consequently rejecting his idea upon the immortality of ethnic consciousness. With reference to her addressing of the Jewish people, she separates herself from Jewish history because like other Jews she has joined them - America, the world at large.

Grace Paley is notably different from Cynthia Ozick. Contrary to Ozick's overt disapproval of rootless America, Paley's is an optimistic celebration of its multicultural community. What she aims to achieve in her account is a story of everyday life. It creates a miniature of a vivid portrait of a complex and contradictory America. She doesn't seem to fear the possibility of the Jewish culture being threatened by American Christianity rather she cheers its probable enrichment by existing alongside it.

Her story "The Loudest Voice" opens with clear elements of a typical Jewish setting thus formulating, since the beginning, a specific social identity. In brief, Shirley, a Jewish child, is initially anxious about appearing in a Christmas play. The involvement of Jewish children, such as Shirley, occasions debate and commentary throughout the Jewish 
community. Likewise in "Envy; or Yiddish in America" these debates take place between those who are in favor and embrace assimilation into primarily Christian America, and those who firmly want to save the integrity of their ethnic and religious identity. The strange idea to create a Christian show with Jewish players to Jewish audience takes us back to the melting pot theory and suggests us that the American education system really wants them to embrace their tradition. The following passages give us a clear picture of how they do this:

That afternoon, all over the building, children scraped and scrubbed the turkeys and the sheaves of corn off the schoolroom windows. Goodbye Thanksgiving. The next morning a monitor brought red paper and green paper from the office. We made new shapes and hung them on the walls and glued them to the doors.[...]The teachers became happier and happier. Their heads were ringing like the bells of childhood. ${ }^{2}$ [...] We learned, "Holy Night" without an error. "How wonderful!" said Miss Glace, the students' teacher. "To think that some of you don't even speak the language!" We learned "Deck the Halls" and "Hark! The Herald Angels" ... they weren't ashamed and we weren't embarrassed. (Paley, 3)

In terms of such influential cultural relativism when we frequently find ourselves talking about western, oriental, Christian, Jewish, youth, or even street culture, it is not easy to argue about culture or multiculturalism, when a lot of emphasis is placed on "diversity" and "identity". Nevertheless, there exists the risk that the edification of cultural identity and diversity as a means of understanding "culture" can lead to reinforcement of stereotypes and barriers among people. What follows is an illustration of such displays in the Abramowitz home, where Shirley's mother disapproves of all the noisy arrangements. Addressing to her husband she remarks:

Misha, you don't know what's going on there. [...] "Listen", she said sadly, "I'm surprised to see my neighbors making tra-la-la for Christmas." [...]If we came to a new country a long time ago to run away from tyrants, and instead we fall into a creeping pogrom, that our children learn a lot of lies, so what's the joke?

(Paley, 36)

${ }^{2}$ Italics, mine. 
Like Edelshtein who is longing for success, she feels that the price of this kind of involvement in American social and cultural arrangements would be the betrayal of Yiddish tradition. On the one hand, Edelshtein was trapped between two ambivalent ambitions: as a poet, he would like to give authentic voice to his past but he would equally like to be read, and there is no community reading in Yiddish any longer. Shirley's mother, on the other hand, if not trying to hold forth their Jewish heritage, at least she would prefer others to respect the silence of their religious and cultural adherence in search of which she and some of her Jewish neighbors appear from the beginning of the story with their begging "Be quiet!" (Paley, 1). But her husband, representing the moderate, flexible spirit who like Shirley speaks his mind, argues by saying: "In Palestine the Arabs would be eating you alive. Europe you had pogroms. Argentina is full of Indians. Here you got Christmas." (Paley, 36) At the end of the story Shirley comes to accept her participation in such a show as a part of American culture.

I was happy. I fell asleep at once. I had prayed for everybody: my talking family, cousins far away, passersby, and all the lonesome Christians. I expected to be heard. My voice was certainly the loudest. (Paley, 40)

Like Hannah in "Envy; or Yiddish in America", she joined them and in a certain sense broke the barriers that their cultural diversity imposed on her. Now she could pray for everyone and this made her happy. Perhaps Edelshtein, Clara Abramowits, Baumzweig, and others needed Shirley's loud voice to steer them out of their Jewish ghetto in order to embrace the world at large. This would be the loud voice of the new generation who understands the dilemma of being a Jew in American soil. "They can't have it both ways" ${ }^{3}$, is the basic punch line of Ozick's joke about this dilemma of the Jewish writer, meaning that they cannot maintain their language and culture and be an integral part of the society and culture of the hosting country. Like Hannah, they have come to learn that there are not good or bad kinds of Jews. There are old and new ones. Their choice? They decided to be the new ones.

Works cited:

Ozick, Cynthia. "Envy; or Yiddish in America". Commentary 48, 1969. (5). Accessed Dec 2013. https://www.commentarymagazine.com/articles/envy-oryiddish-in-america-a-novella/

\footnotetext{
${ }^{3}$ In an interview with Elaine M. Kauvar in 1993.
} 
Kauvar, Elaine M. "An Interview with Cynthia Ozick" Contemporary Literature Bloomington: Indiana University Press, 1993. 34. Print

Kramsch, Claire. "Language and Culture". Oxford: Oxford University Press. 1998. Print.

Paley, Grace. "The Loudest Voice." The Collected Stories. New York: Farrar, Straus and Giroux, 1994. Print

\section{LE SALADIER JUIF DANS LE MELTING POT AMÉRICAIN: UNE CONTEMPLATION LITTÉRAIRE}

L'histoire de l'humanité a toujours été caractérisée par des cycles répétés de crises et de périodes de transition entraînant la transformation de divers aspects de la coexistence et de l'interaction des hommes, que ce soit au niveau individuel, ethnique, national ou même international.

À l'heure actuelle, nous sommes devenus des témoins oculaires de ce que l'on peut appeler les croisades et l'exode des temps modernes. La libre circulation actuelle des personnes imposée par la tendance à la mondialisation dans la société contemporaine, et en particulier la nouvelle vague de migrations accompagnée de la crise des migrants qui en découle et déclenchée par de nombreux conflits armés au Moyen-Orient, établira sans aucun doute de nouvelles relations entre les différentes ethnies, groupes d'appartenance religieuse différente et même entre migrants et pays d'accueil.

Au cours de ces périodes de transition historiques, les entités concernées ont tenté de définir et d'expliquer ces relations et interactions humaines pouvant varier de l'assimilation au multiculturalisme. Les deux métaphores utilisées pour définir les nouvelles formes de langage, les coutumes et la coexistence culturelle sont celles liées aux notions de melting pot et de salad bowl, qui seront abordées avec une référence littéraire à "La voix la plus forte" de Grace Paley et à " L'envie; ou Yiddish en Amérique" de Cynthia Ozick. Dans ces deux écrits, la nécessité de transcender l'aliénation, de même que le souci d'exprimer l'appartenance à des prémisses naturalistes américaines, suggéreront un effort pertinent et analogue d'identification à celui des migrants errant dans les rues d'Europe occidentale à la recherche d'un endroit paisible où habiter et cohabiter avec le pays hôte et la culture implicite.

Mots-clés: assimilation, multiculturalisme, melting pot, saladier, appartenance culturelle. 